\title{
ON CHEMICAL DENUDATION CAUSED BY GROUND WATER IN CENTRAL FINNISH LAPLAND
}

\author{
Pertiti Lahermo
}

\begin{abstract}
Lahermo, Pertti 1971: On chemical denudation caused by ground water in central Finnish Lapland. Bull. Geol. Soc. Finland 43, 233-245.

In the study an estimate was made of the chemical denudation caused by ground water discharged from surficial deposits, on the basis of the dissolved inorganic matter, during the late and postglacial period of approximately 10000 years. The calculations are based on the premise that in only a gently sloping, till-mantled tract the infiltration coefficient of the ground water varies between 0.20 and 0.40 , and in level tracts covered with sand and gravel between 0.40 and 0.60 . Further, the amount of annual precipitation taken into account in the calculations varies from 450 to $500 \mathrm{~mm}$, and the dry unit weights of the till and the stratified drift amount to 1.60 and $1.70 \mathrm{t}$ per $\mathrm{cu}$. $\mathrm{m}$. The assumption was made that the postglacial fluctuations in climatic conditions in one and another direction cancel each other out to the extent that they do not significantly affect the calculations. The appreciable amounts of matter brought down out of the atmosphere by the rain have been taken into account.

The chemical denudation caused by ground water percolating through till in areas of silicic bedrock corresponds to the elimination of a soil layer of between 2.0 and $4.5 \mathrm{~cm}$ in thickness, the corresponding value in areas of subsilicic bedrock being 5.5 to $11.0 \mathrm{~cm}$. In silicic bedrock areas the chemical denudation is slightly more intensive in stratified drift than in till deposits. Not taking into account the composition of the surficial deposits and the bedrock, the average rate of chemical denudation in the whole study area was found to be from 2.4 to $5.8 \mathrm{~cm}$. This finding is in agreement with the calculations made on the basis of brook and river waters.
\end{abstract}

Pertti Labermo, Institute of Geology, University of Oulu, Oulu, Finland.

\section{The formation of ground water and its relation to surface waters}

Water falling as rain on the slopes of the wooded till-mantled hills of the study area (Fig. 1) forms ground water, which flows in the direction of the gradient (Fig. 2). Some of the ground water is retained only a short time below the surface, being discharged on the lower slopes as little springs or as surface seepage. Water of this type does not always reach the actual groundwater table at all but occurs as perched water in the more permeable layers of soil close to the surface. The discharge of ground water as springs at the foot of hills generally takes place in the marginal zones of surrounding bogs (Fig. 2, 3, Lahermo 1970 a, Fig. 6). 


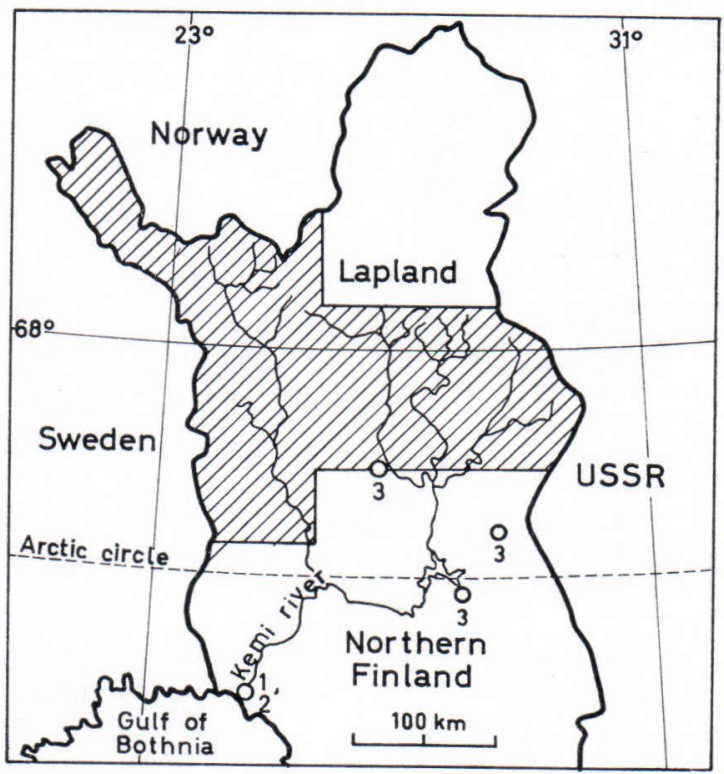

FIG. 1. Location of the study area. The water samples were collected from the shaded area, with the majority of the sampling sites being concentrated in the southern part of this area. The numbered sampling sites represent monthly observations of river or brook waters $(1=$ Holmberg 1935, 2 = Viro 1953, 3 = Väre 1961, symbols $111,112,114)$.

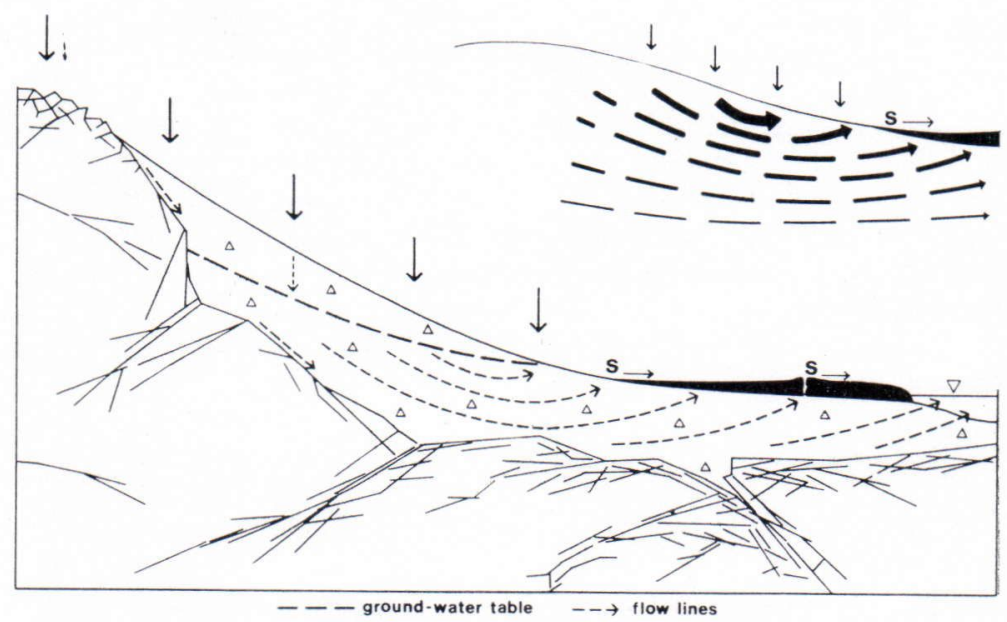

FIG. 2. Schematic drawing to show the formation of ground water and its percolation down the slope of a tillmantled hill. Insofar as the till underlain by weathered and fissured bedrock is homogeneous, the course of flow of the ground water is curved, being directed toward the discharge area, owing to the force of gravity. Ground water is discharged into surface waters either through springs (S) in the marginal zone of bogs (black) or directly out of surficial deposits. Close to the surface, the rate of flow of ground water is higher and the course of flow more curved than deeper down, where the ground water flows slowly. This is depicted by the sketch in the upper righthand corner, in which the rate of flow is indicated by the thickness of the arrow. 
Kittilä, Palolaki

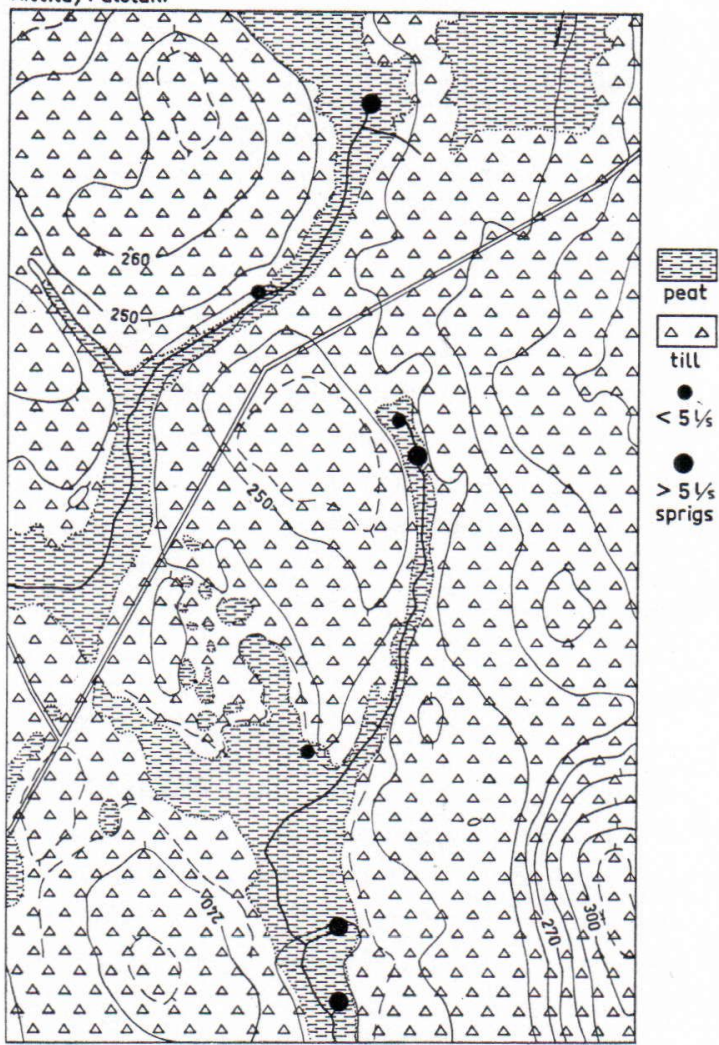

FIG. 3. Brooks that are fed by ground water discharged out of surficial deposits. Springs occur at the foot of till-mantled wooded hills in gullies situated between the hills. In areas of this type, the surface runoff is slight hence the brooks are effluent. Palolaki, sout hwest side of Pokka, Kittilä commune.

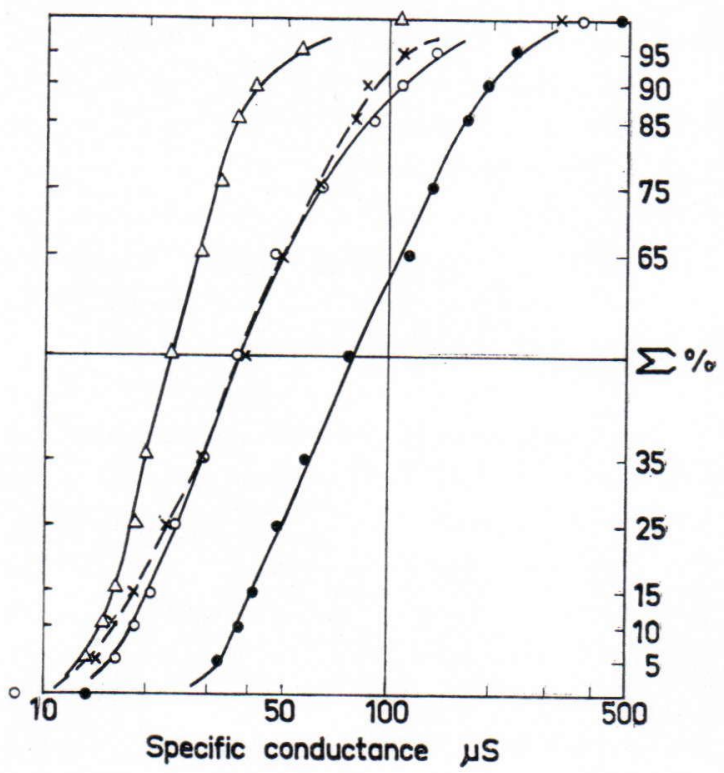

FIG. 4. The frequency distribution of specific conductance values represented as cumulative curves. Triangle (curve 1 ) $=$ ground or perched water retained only a short time in surficial deposits and discharged to the surface as small springs or as seepage. Open circle $(2)=$ ground water discharged as springs from surficial deposits. Cross $(3)=$ brook water. Black circle $(4)=$ ground water contained in fractures and fissure zones of bedrock. The similarity between the distributions of the specific conductance values (curve 2, 3) indicates that the brook waters are mainly ground water discharged from surficial deposits.
Perched water or ground water that is percolated only a short time in surficial deposits cannot effectively dissolve the mineral matter of its environment. For this reason, such water contains but few electrolytes (Fig. 4, curve 1). Ground water that has remained longer in surficial deposits, and forms in some instances large springs at the foot of a hill, is more electrolytic (curve 2).

In winter as well as during dry spells in summer, when the surface runoff has completely ceased or is at best very slight, the water running in brooks is solely ground water being discharged out of the surficial deposits. Many brooks origi- nate in large springs, and the flow of water in the brooks increases all along because more and more ground water is being fed into them (Fig. 3). Brooks and rivers naturally flow in depressed parts of the terrain, where the percolation of the ground water likewise is directed. Not nearly always does ground water rise to the surface in the form of springs, however, for it frequently percolates straight into watercourses through surficial strata, which in low-lying places are commonly covered with peat (Fig. 2, 3). The close connection between the water in brooks and the water being discharged out the ground is further indicated by their chemical similarity. 
Both ground water and brook water contain electrolytes in approximately equal amounts (Fig. 4, curves 2 and 3, Lahermo 1970 b, Fig. 4).

Deep down in fractures and fissure zones of bedrock, ground water flows and thus changes slowly. Even before it has passed down into the bedrock, ground water has in many cases percolated through a bed of surficial deposits of varying thickness, dissolving the mineral constituents. Further, water retained in the bedrock for a long time tends to have a notable dissolving effect on surrounding minerals. Indicative of this is the high electrolyte content of ground water obtained from bedrock (Fig. 4, curve 4). Hence the interchange between ground water deep in bedrock and surface waters is slight.

It has been observed through laboratory experiments and theoretical calculations that in approximately homogeneous surficial deposits the course followed by ground water percolating in the direction of the gradient is curved because of the force of gravity (see Tolman 1937, Figs. 66-67, Gustafsson 1968). Close to the ground surface, the course of flow of rapidly percolating ground waters is the most conspicuously curved. By contrast, at a depth the course of slowly percolating ground water is only very slightly curved. Figure 2 schematically illustrates the formation of ground water and the course of its percolation down the slope of a hill mantled with homogeneous surficial deposits, usually till.

The curved form of the course followed by percolating ground water is partly responsible for the circumstance, noted in the foregoing, that brook waters consist mostly of ground waters that have been discharged from surficial deposits. In reality, the paths followed by percolating ground waters are regulated to a significant extent also by the layered structure of the deposits and the differences in the permeability of the different layers. In bedrock, again, the direction of flow of ground water is determined by the fractures and the fissure zones.

The till-covered hills of central Lapland are generally broad and gently sloping. The till is rich in fine and medium-coarse sand (Kujansuu 1967, Fig. 7; Lahermo 1970 a, Fig. 4), in which there is some silt, too. Consisting in their surficial layers of loose material, the till deposits commonly contain sorted sand and gravel lenses or beds, some of them of considerable extent. Accordingly, the till is moderately permeable, which means that during the periods when the ground has thawed out the surface runoff on the gentle slopes is slight. It occurs mainly in the spring during the melting of the snow and during exceptionally heavy rains.

In tracts of sand and gravel with nearly flat surfaces, like sandur and delta deposits, practically no surface runoff occurs. All the water that does not evaporate directly off the ground and plants or by transpiration ends up as gravitational and ground water. In dry summers, evaporation is heavy; this means that the resources of ground water receive little or no new supplies of water, which is the same situation in winter, too ( $c f$. ., Ristola 1968). In the spring, when the snows melt, and in the fall, during the rainy season, the temperature is low and there is less evaporation as well. It is during these periods that the ground-water supplies are chiefly replenished. The ground water thus formed is discharged as springs or flows directly into bodies of surface water out of the ground.

In spring, ground frost, the thickness of which is apt to be several meters (see, e.g., Jansson 1968), prevents melt waters in many places to reach the ground-water table. In the end, however, the melt waters bring about an abrupt rise in the ground-water table, after its gradual drop during the winter (see Hyyppä 1962; Johansson, Soveri 1965).

In central Lapland the portion of the annual precipitation that is infiltrated is dependent on many factors. These include, inter alia, the amount of precipitation and its distribution over the different seasons of the year, variations of temperature and the closely connected evaporation. Also topographic and floral as well as, above all, geological factors contribute 
significantly to the formation of ground water. Among the last-mentioned factors, especially the density of the woods and plant cover and the content of fine-grained material in the surficial deposits are influential. In extensive flat boglands, where the ground-water table is high, evaporation and surface runoff are dominant phenomena, so ground water is not formed to any significant degree.

Few studies have been made on the amount of ground water forming in till deposits. According to Vanhala (1959), only 18 or 19 per cent of the annual precipitation forms ground water in areas partly covered with till (infiltration coefficient: $0.18-0.19)$. The corresponding value reported by Troedsson (1955) from central Sweden is as low as 13 per cent; and the infiltration coefficient worked out by von Brömssen (1968) is $0.11-0.18$. The figure obtained by Ristola (1968) for ground water produced in a sandy till area from the annual precipitation is between 20 and 30 per cent.

The available information on the formation of ground water in tracts covered with sand and gravel is likewise rather haphazard. Sederholm (1909) reached the conclusion that in depositions of sand and gravel like Salpausselkä at most 50 per cent of the annual precipitation is infiltrated to become ground water (infiltration coefficient: 0.50). According to Vanhala's (1959) calculations, which are based on test pumpings, the infiltration amounts in areas covered with sand and gravel are no more than 29 per cent of the annual precipitation. According to Ristola's (1968) lysimetric studies in the Salpausselkä ranges, the amount of infiltration is between 40 and 60 per cent. In the esker areas of Sweden, the infiltration coefficient obtained by von Brömssen (1968) is between 0.34 and 0.80 . Best applicable to the present study area are Hyyppä's investigations (1962) in the northern section of Sodankylä dealing with variations in the ground-water table. The results reported by Hyyppä are that in a level sandy tract, from 42 to 61 per cent of the annual precipitation ends up as ground water.

\section{The basis for estimating the chemical denudation caused by ground water}

Ground water discharged into surface waters continuously carries with it out of the ground inorganic matter, which has naturally been dissolved through weathering of mineral substances. In the foregoing, the observation has already been made that brooks and small rivers are fed mainly by ground water discharged out of the surficial deposits. The products of chemical denudation caused by percolating ground water are eventually emptied, along with the waters of brooks and rivers, into the sea. On the basis of the amount of matter dissolved in ground water, an estimate can be made of the quantity of inorganic matter that has been removed annually or during the entire postglacial period from, for example, a piece of land a square meter in area. That is, the magnitude of the chemical denudation can be worked out. This presupposes, however, that the composition of the ground water being discharged into surface waters is known, together with the changes taking place at different seasons of the year as well as the quantity of discharged ground water.

With regard to the quality of the ground water fairly numerous observations have been made in the study area in both summer and winter (see Lahermo 1970 a). Investigations have proved that the quality of the ground water discharged from large springs remains fairly constant throughout the year (Fig. 5). The most difficult research problem, then, is estimating the volume of ground water being discharged out of the surficial deposits.

Taken as the point of departure for estimating the amount of chemical denudation are, according to the results presented afore and the estimates arrived at in the study area, the following infiltration coefficients: on gentle slopes covered with till poor in fine-grained matter and, in additon, characterized by rather meager vegetation, between 0.20 and 0.40 ; on level tracts of sand and gravel, thanks to the better permeability of the sediments, between 0.40 and 0.60 . 


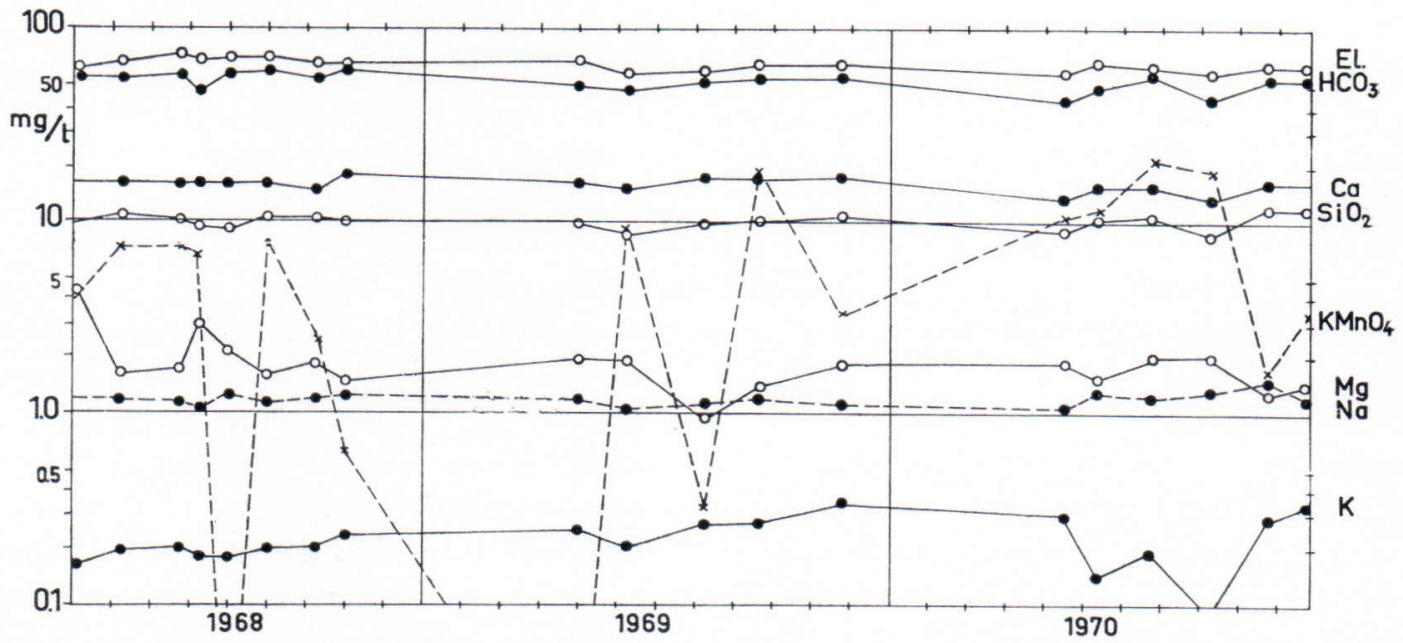

FIG. 5. The variations in the chemical composition of the ground water discharged from surficial deposits during a period of three years. The concentrations of the main components remain fairly constant throughout the year. On the other hand, the humus content, as represented as $\mathrm{KMnO}_{4}$ consumption values, varies greatly, depending on the amount of the surface runoff infiltrating into the ground water. El = average electrolyte content, which has been obtained by multiplying the specific conductance value by the coefficient 0.75 . Large spring at south end of Nuokkioselkä, Kittilä commune.

The average annual precipitation has been estimated as being between 450 and $500 \mathrm{~mm}$ ( $c f$., HVK 1968, appendix V). It is because of the wide range of variation in the infiltration coefficients and the precipitation that the minimum and maximum amounts of denudation obtained from the values above deviate considerably from each other ( $c f$. , Table 1).

A factor leading to inexactness in the calculations is, of course, the uncertainty of the infiltration coefficient. On the other hand, it is inconceivable that it might be precisely worked out for an extensive study area. Moreover, any infiltration coefficient must vary, even considerably, in successive years, owing to meteorological conditions.

Uncertainty into the calculations is further introduced by the difficulty of estimating the amounts of matter brought down by rain water. The substances coming out of the atmosphere contribute significantly to the composition of ground waters, and they must therefore be taken into account in calculating the rate of chemical denudation. The amounts of matter contained in rain water may have changed somewhat during the postglacial period. The sulfate content of the atmosphere has apparently increased in modern times, owing to industrial activity and the increased utilization of fossil fuels. The increased presence of other substances in rain water does not significantly affect the calculations, owing to their small amounts.

In addition, it is probable that matter falls down to earth from the atmosphere not only with rain water but also as a continuous deposition of very small particles (see, e.g., Eriksson 1955). This increases the amount of atmospheric matter in Table 1, which has only been calculated according to the composition of the rain water (section 3). The last-mentioned factor in turn decreases the amount of chemical denudation presented in section 4. We do not, however, have information on the amounts of matter carried into ground waters in the study area through the deposition of small particles or the agency of fog or dew.

The point of departure in calculating the rate 


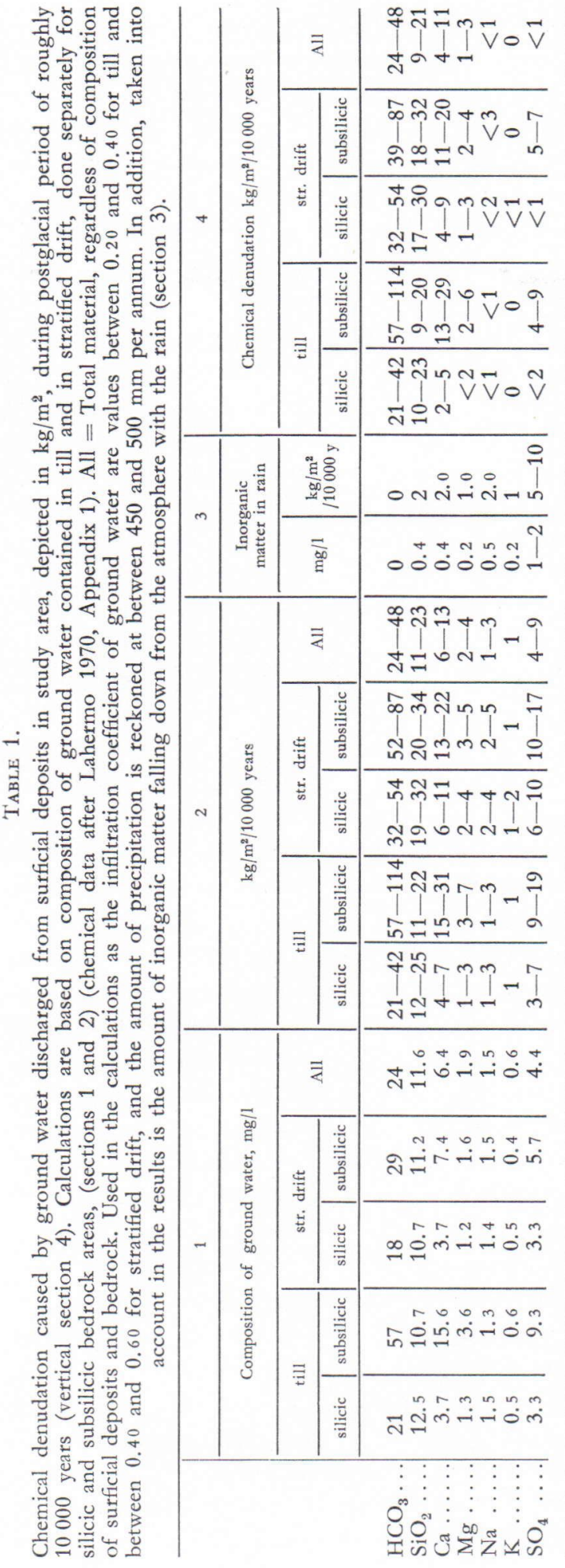

of denudation since the Ice Age is that the study area became deglaciated roughly 10000 years ago. The eastern parts of the region probably emerged out of the ice as long as 11000 to 12000 years ago and the western parts not more than about 9000 years ago (see Kujansuu 1967, Lappalainen 1970). From the standpoint of the results, such slight differences have no fundamental significance, considering the other possibilities of error.

During the postglacial period, the average temperatures have varied greatly (see, e.g., Magnusson, Lundqvist, Regnell 1963, p. 629). This circumstance plus the fact of the deviating distribution of land and water at present has brought about changes in precipitation and evaporation. These in turn have affected the infiltration coeffients of ground water. The 1.5 to $2.0^{\circ} \mathrm{C}$ higher mean temperature prevailing during the Litorina stage probably produced a slightly higher precipitation (Aario 1969, p. 10), although this is not certain. Nevertheless, the evaporation must have been greater, too, on account of the higher mean temperature, with the result that despite the possible higher precipitation less ground water formed than nowadays. For this reason, the ground-water table was at a lower level during the Litorina. Indicative of the dryness of the climate and the lowness of the groundwater table are the recurrence levels in bogs to be met with also in this country in some places (cf., Brandt 1948). On the other hand, the higher temperature and the longer frost-free season made possible a slightly more effective chemical denudation, notwithstanding the smaller volume of ground water being discharged to the surface. Prior to the Litorina stage, there had been periods of a colder climate, during which ground water was produced more abundantly. Following the Litorina, the mean temperature dropped to the present levels, as a consequence of which more ground water is formed out of less precipitation by virtue of reduced evaporation. The groundwater table rose and the process of paludification evidently gained momentum. To summarize the 


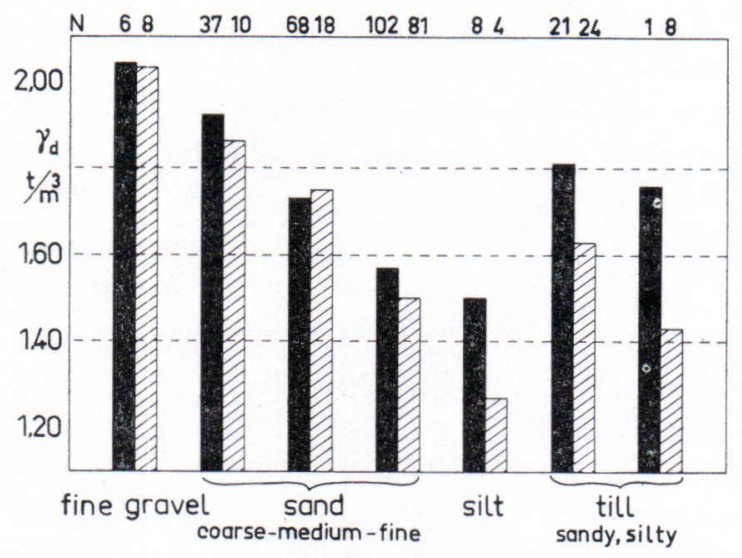

FIG. 6. The dry unit weights of different types of soil, according to water volumeter determinations (after unified soil classification system). Ruled column on right represents unit weights of surface layer of soil (less than $1 / 2 \mathrm{~m}$ deep) and black column on left, those of deeper layers. Columns represent arithmetic means of determinations, the number of which (N) is marked on top of each column. $\mathrm{t} / \mathrm{m}^{3}=$ tons per cubic meter.

foregoing, it may be assumed that the conditions of chemical denudation have not changed during the whole postglacial period to the extent of essentially affecting calculations. Fluctuations in climatic conditions in one and another direction cancel each other.

The calculations on the amount of chemical denudation might be graphically represented as the height of the column of soil eliminated. In order to undertake such a calculation, one must, however, know the dry unit weight of the soils in the study area. According to measurements made with a water volumeter, the dry unit weights of the surficial portion of the soil are on the average lower than those of deeper layers (Fig. 6). This is but natural, for the deposits at the surface are susceptible to weathering and to the action of roots and frost. In the calculations, the unit weight of the till used was $1.60 \mathrm{t} / \mathrm{m}^{3}$. The rather low value was selected because the surficial portion, where weathering occurs most intensely, is generally loosely deposited till being the sort of material found in ablation moraines. The unit weight of the sand and gravel as used in the present calculations was $1.70 \mathrm{t} / \mathrm{m}^{3}$.
The ground water discharged out of the surficial deposits does not contain suspended material to any notable degree, which means that mechanical denudation need not be taken into account. The quantity of organic matter is likewise slight. The values for $\mathrm{KMnO}_{4}$-consumption are on the average only $2-4 \mathrm{mg}$ per liter (Lahermo 1970 a, Table 5). The humus content of the ground water is at its maximum in spring while the snow is melting, when more than the usual amounts of humus are washed off the surface stratum of soil into ground waters ( $c f$. Fig. 5). From the standpoint of the chemical denudation caused by percolating ground water, this circumstance is of no fundamental importance inasmuch as the content of inorganic material in the water remains largely unchanged.

\section{Chemical denudation caused by ground water}

The chemical denudation caused by ground water is two to four times as great in areas of subsilicic bedrock (mainly greenstones, black schists, amphibolites, gabbros) as it is in areas of silicic bedrock (mainly granites, quartzites, various gneisses and light schists) (Table 1). In subsilicic bedrock areas, the height of the column representing the amount of eliminated till deposits is $7-11 \mathrm{~cm}$, whereas in silicic bedrock areas it varies between $2-4.5 \mathrm{~cm}$ (Fig. 7). Among the cations, calcium and magnesium are the most important substances removed through denudation. On the other hand, sodium and potassium are introduced into ground waters in such large quantities with rain water that the amounts derived from weathering appear to be slight(Lahermo 1970 a, Table 8). The leaching of alkali metals in the weathering process thus scarcely shows up in the column (Fig. 7). The proportions of iron and manganese in the denudation losses are so slight that their removal is not seen in the column, either. This is because, in the main, the ground waters discharged from the surficial deposits are nearly saturated with 


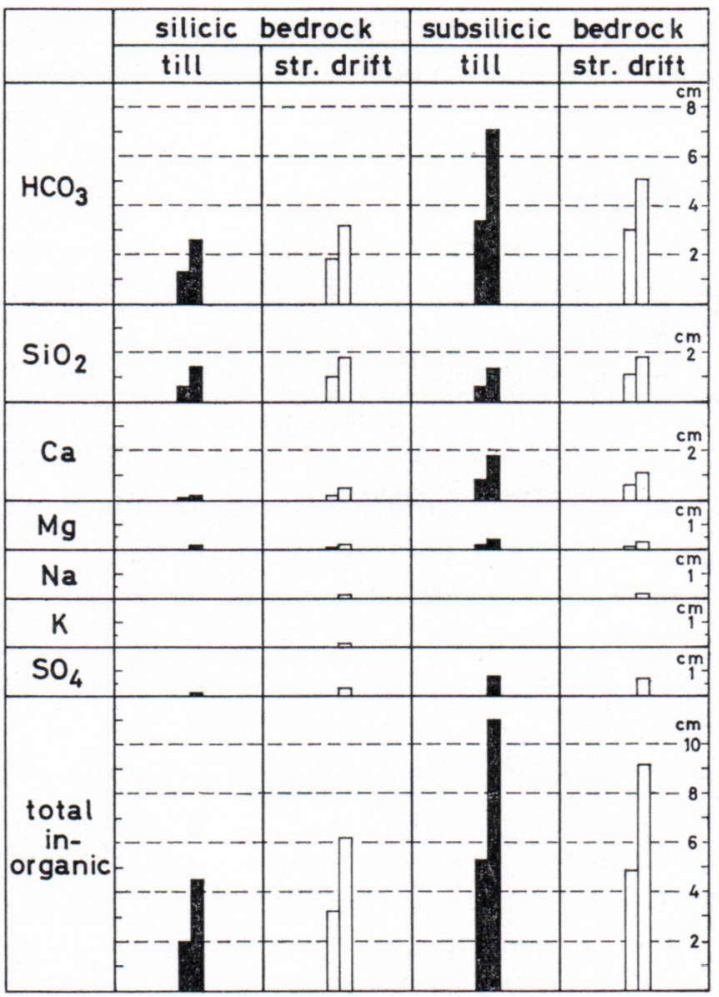

FIG. 7. Chemical denudation caused by ground water, depicted as a column representing the amount of eliminated soil (calculations are based on data from Table 1). In the horizontal rows are represented the most important elements and compounds dissolved in ground water according to the part played by them in chemical denudation. In the lowest horizontal row is represented the chemical denudation as calculated on the basis of the total amount of dissolved inorganic matter. The dry unit weights of the till and stratified drift used in the calculations are 1.60 and $1.70 \mathrm{t} / \mathrm{m}^{3}$ ( $c f$., Fig. 6).

oxygen (see Lahermo 1970 a, Table 4) with the result that the iron compounds are precipitated into the soil.

Of the anions, bicarbonates are removed by far the most (Table 1, Fig. 7). They are predominantly derived from the weathering of silicate minerals and, to a lesser extent, of carbonate minerals (see Stevens 1934, p. 1). The minerogenic origin of the bicarbonates is indicated by the fact that in weathering they are released into ground water three times more effectively in subsilicic than in silicic bedrock areas. This circumstance also suggests that bicarbonates arc not created, at least in any noteworthy amounts, through the decomposition of organic humus material, for the quantity of vegetation, and therefore humus, is not essentially greater in areas of subsilicic bedrock. Moreover, the ground waters of silicic bedrock areas have been observed to contain slightly more humus, as is revealed by the higher values of $\mathrm{KMnO}_{4}$-consumption (Lahermo 1970 a, Fig. 31). On the other hand, an essential part in the decomposition reactions of silicate and carbonate minerals is also played by carbon dioxide, which forms bicarbonates as a reaction product (see, e.g., Stevens 1934, Keller 1957, p. 43; Eriksson, Khunakasem 1968, p. 108). According to this, also organogenic carbon dioxide takes part in the formation of bicarbonate, whereupon the part played by bicarbonate in chemical denudation may be somewhat excessive, just as is the total amount of chemical denudation, too. Bicarbonates do not occur practically at all in rain water, owing to its low $\mathrm{pH}$-value.

In deep layers of surficial deposits, the carbon dioxide content is high (e.g., Bear 1955, p. 205). As carbon dioxides hydrolyze, carbonic acid forms, the quantities being, however, only between 0.1 and 0.6 per cent (Hutchinson 1957, p. 655). Carbonic acid dissociates only to an exceedingly slight degree into bicarbonates (Ohle 1934, p. 430). No noteworthy amounts of bicarbonates are created this way. This is indicated by the fact, too, that the $\mathrm{HCO}_{3}$ contents of electrolyte-poor ground waters in areas of silicic bedrock are lowest, although the $\mathrm{CO}_{2}$ contents are at a maximum (see Lahermo 1970 a, Table 3, Fig. 11).

Silica is leached in both silicic and subsilicic bedrock areas in equivalent amounts by denudation, the height of the eliminated soil column being about $1 \mathrm{~cm}$ (Table 1, Fig. 7). Sulfates occur in rain water in such abundance that their removal by chemical denudation is felt only in areas of subsilicic bedrock. Although the sulfate 
content of acid rain water as a factor promoting weathering or chemical denudation has heavily increased in modern times, it has no great significance in relation to the amount of chemical denudation that has taken place during the entire postglacial period. Insofar as too high a sulfate content has been used in the calculations for rain water, its effect on the height of the column presented in Fig, 7 amounts at most to only a few additional millimeters. The nitrogen compounds and chlorides are principally derived from the atmosphere, meaning that their contents in ground water are not the result of chemical denudation. The fluoride and phosphate contents are so slight(Lahermo 1970 a, Appendix 1) that they have no essential significance in calculating the height of the column representing the eliminated soil through chemical denudation.

In subsilicic bedrock areas the chemical denudation caused by ground water is slightly more effective in till than in sorted glaciofluvial material (Fig. 7). This is due to the higher content of finegrained constituents in till, which intensifies the leaching of the mineral matter. The lesser permeability of the till has an effect of the same nature, as there is more time for the process of dissolution with its multiplicity of chemical phenomena. However, in more permeable, stratified drift, a greater quantity of ground water forms and thus also discharges into surface waters. For this reason, the rate of chemical denudation caused by ground water in silicic bedrock areas is slightly higher in sorted glaciofluvial material than in till.

\section{Comparison of the results}

The amount of denudation has previously been estimated principally on the basis of the material dissolved in river waters and occurring in suspension. Investigations along this line have enjoyed good opportunities since data relating to the chemical composition, runoff and discharge of river waters have been collected in many countries ever since the last century.
Characteristic of brook and river waters are the great variations in their chemical composition at different seasons of the year (see, e.g., Holmberg 1935). The quality of the waters is most even in winter, when surface runoff is at a standstill, as well as during long dry spells in summer. During the spring flood season and during times of heavy rains, the waters contain on the average small amounts of dissolved matter. Nevertheless, at such times the volume of water flowing is manifold, compared to normal (see, e.g., Väre 1961, Figs. 6-8), indicating the possibility of a higher rate of denudation, too. These circumstances lead to difficulties in the estimation of the rate of denudation on the basis of the contents of material in brook and river waters. This is especially true when the observations of discharge are not continuous or - what is more common - the sampling frequency has been insufficient. A factor adding to inaccuracy in results is industrial and agricultural activity along the banks of major rivers, activity that augments the constituents of the water.

When the material suspended in ground water being discharged to the surface is slight in amount, the corresponding contents in river waters are significantly higher. The highest content of suspended material, representing mechnical denudation, occurs during the spring floods. At this season, the content of material in suspension in, e.g., the Kemi river is of the magnitude of 10 per cent, whereas normally the figure is only a few per cent (see Holmberg 1935, Fig. 7, Table 3, 32-34). The principal portion of the suspended material probably originates from the main course of the river, which means that mechanical denudation has no fundamental significance in the areas of till and stratified drift along the upper tributary streams.

In the following the chemical denudation caused by ground water is compared to the chemical denudation calculated for the Kemi river and some of the smaller rivers or brooks in the same drainage area (Fig. 8). In vertical section No. 1, the chemical denudation is rep- 
resented as the height of the column of eliminated soil, calculated on the basis of chemical analyses of the Kemi river carried out in the period 1918-1931 (Holmberg 1935, Table 3, 32 -34). During the years in question, settlement activity and water-construction works along the river had not yet affected the composition of the water to the same degree as at present. Section No. 2 represents the chemical denudation calculated according to the analytic material compiled by Viro (1953, Table 5) during a period of one year. The corresponding calculations have been made in section No. 3 on the basis of the dissolved material contents of three brooks, representing two years'statistical data (Väre 1961, Table 5, symbols 111, 112, 114). The sampling sites are presented in Fig. 1. Section No. 4 represents the chemical denudation caused by ground water discharged from the surficial deposits in the study area likewise in the form of the column representing the height of removed soil. In all these calculations, the proportion of material brought down by the rain has been taken into account in accordance with Table 1 (section 3).

The results in Fig. 8 show that the amounts of chemical denudation calculated on the basis of the dissolved material contents and volume of water in the rivers and brooks are of the same order of magnitude (sections $1-3$ ). The denudation represented in section No. 2 is the lowest, but the calculation is based only on the material collected during a single year. In successive years, the amounts of material transported by rivers and brooks are likely to vary quite conspicuously ( $c f$. , Väre 1961, Figs. 27-28).

The chemical denudation caused by ground water varies considerably in different areas, and it is on the average slightly lower (section 4) than the corresponding values registered for river and brook waters.

As a whole, the chemical denudation caused by ground water discharged from the surficial deposits in the study area corresponds to the elimination of between 2.4 and $5.8 \mathrm{~cm}$ thick layer

\begin{tabular}{|c|c|c|c|c|}
\hline & 1 & 2 & 3 & 4 \\
\hline $\mathrm{HCO}_{3}$ & & & & \\
\hline $\mathrm{SiO}_{2}$ & & & & \\
\hline $\mathrm{Ca}$ & & & & \\
\hline $\mathrm{Mg}$ & & & & \\
\hline $\mathrm{Na}$ & & & & \\
\hline & & & & \\
\hline K & & & & \\
\hline $\mathrm{SO}_{4}$ & & & & \\
\hline total & & & & \\
\hline $\begin{array}{l}\text { in- } \\
\text { organic }\end{array}$ & & & & \\
\hline
\end{tabular}

FIG. 8. The amount of chemical denudation caused by ground water in the study area (vertical section 4), compared with the chemical denudation calculated on the basis of the composition of river and brook waters (sections $1-3$ ). The results are presented as a column representing the amount of eliminated soil just as in Fig. 7. Section $1=\mathrm{Kemi}$ river in the period 1918 - 1931, $2=$ Kemi river in 1952-1953 ( 1 year), and $3=$ three brooks in 1959-1960 (cf., Fig. 1).

of the soil (Fig. 8). The corresponding figures calculated for brook and river waters are between 3.3 and $5.7 \mathrm{~cm}$. If we takes into account that the carbon dioxide needed in the formation of bicarbonates principally comes from atmosphere or decomposition products of organic matter, the real chemical denudation is slightly less than presented above ( $c f$.p. 241). Hyyppä (1969, p. 92) has reported the value of $0.35 \mathrm{~cm}$ for the thickness of eliminated soil layer removed in the glaciofluvial Salpausselkä range through chemical denudation during the past 1000 years (infiltration coefficient 0.30 ). The value arrived at in Sweden on the basis of the inorganic matter dissolved in rivers flowing through till-mantled tracts (Eriksson 1929) varies between 5.6 and $6.0 \mathrm{~cm}$, depending somewhat on the amount of material brought down by rainfall. Arrhenius (1954) has reported from Sweden that the topmost meter of the soil has lost about one-fifth of 
its weight by denudation since the Ice Age. He arrived at this high result in the light of the large quantities of material contained in ground water present deep in the surficial deposits and in the bedrock.

In Finland, chemical denudation is slight compared to the amounts reported from other parts of the world, which are from ten to thirty times greater (see Viro 1953, p. 29). Contributing factors elsewhere are, in addition to more favorable climatic conditions, primarily the composition of the surficial deposits and the bedrock. The ancient Archean Finnish bedrock, which is built of metamorphic and plutonic rocks, consists mainly of silicate minerals that are highly resistant to weathering.

\section{REFERENCES}

Aario, R. (1969) The northern discharge channel of ancient Päijänne and the paleohydrology of the Atlantic period. Bull. Geol. Soc. Finland 41, pp. 3-20.

Arrhenius, O. (1954) Chemical denudation in Sweden. Tellus 6, n:o 4, pp. 326-341.

Bear, F. E. (1955) Chemistry of the Soil. Reinhold Publ. Co, New York. 373 p.

Brandt, A. (1948) Über die Entwicklung der Moore im Küstengebiet von Süd-Pohjanmaa am Bottnischen Meerbusen. Vanamo, Tom. 23, n:o 4, pp. 1-134.

vON BRÖMSSEN, U. (1968) Grundvattenbildning i geologiskt olika terrängavsnitt, försök till bestämning av infiltrationskoefficienter. Summary: Ground water formation in geologically disparate sections of terrain, an attempt to determine infiltration coefficients. Metod-Teknik-Analys, pp. 33-110.

Eriksson, E. (1955) Air borne salts and the chemical composition of river waters. Tellus 7 , n:o 2, pp. $243-250$.

Eriksson, E., Khunakasem, V. (1968) The chemistry of ground waters. In "Ground Water Problems», pp. 89-122. Edited by Eriksson, E., Gustafsson, Y., Nilsson, K. Pergamon Press, Oxford. 223 p.

Eriksson, J. V. (1929) Den kemiska denudationen i Sverige. (La dénudation chimique en Suéde). Medd. Statens Meteorolog. Hydrogr. Anst. 5, pp. 1-92.

Gustafsson, Y. (1968) The influence of topography on ground water formation. In "Ground water Problems», pp. 3-21. Edited by Eriksson, E., Gustafsson, Y., Nilsson, K. Pergamon Press, Oxford. 223 p.

Holmber G, L. (1935) Ergebnisse optischer und chemischer Wasseranalysen 1911-1931. Hydrologisen Toimiston Tiedonantoja V. Helsinki, pp. 1-54.

Hutchinson, G. E. (1957) A Treatise on Limnology. I. Wiley \& Sons, Inc., New York. 1015 p.

HVK, (1968) Hydrologinen Vuosikirja 19. Hydrologinen Toimisto, Tie- ja Vesirakennushallitus, Helsinki, pp. $1-97$.
Hyyppä, J. (1962) Pohjavesitutkimuksia Sodankylän pitäjän pohjoisosaan suunnitellun Lokan patoamisaltaan ympäristössä (unpublished). Helsingin Yliopiston Geologian ja Paleontologian laitos, Helsinki.

- (1969) Pohjavesi (ground water). Explanatory text to the map of Quaternary deposits, sheet 2044, Riihimäki. Geological Survey of Finland, Otaniemi, pp. 90-92.

JANSON, L-E. (1968) Tjäldjupet i Sverige. Summary: Ground frost depth in Sweden. Inform. f. Statens Naturvårdsverk 4.

Johansson, S., Soveri, U. (1965) Om grundvattenytans variation i Finland under åren 1961-1963. Valtion Teknillinen Tutkimuslaitos, Tiedotus. Sarja III, Rakennus 88, pp. $1-36$.

Keller, W. D. (1957) The Principles of Chemical Weathering. Lucas Brothers Publishers, Columbia, Missouri, $111 \mathrm{p}$.

Kujansuu, R. (1967) On the deglaciation of western Finnish Lapland. Bull. Comm. Géol. Finlande 232, pp. 1-98.

Lahermo, P. (1970 a) Chemical geology of ground and surface waters in Finnish Lapland. Bull. Comm. Géol. Finlande 242, pp. 1-106.

- (1970 b) Om grund- och ytvattnens kemiska geologi i Finska Lappland. Nordisk Hydrologisk Konferens, Stockholm 27-29 aug. 1970. Volum 2, pp. 197-208.

LAPPALAINEN, E. (1970) Über die spätquartäre Entwicklung der Flussufermoore Mittel-Lapplands. Bull. Comm. Géol. Finlande 244, pp. 1-79.

Magnusson, N., Lundvist, G., Regnéll, G. (1963) Sveriges Geologi. Svenska Bokförlaget, Norstedts. 698 p.

Ohle, W. (1934) Chemische und physikalische Untersuchungen norddeutscher Seen. Arkiv für Hydrobiologie 26 .

RistolA, P. (1968) Grundvattnet och dess användning i Helsingforstrakten. Värme och Sanitetsteknikern 3, pp. $37-42$. 
Sederholm, J. J. (1909) Om grundvattnet i Finland, dess förekomst och rörelser. Geotekn. Julk. 4. Geologinen Komissioni, pp. 1-26.

Stevens, R. E. (1934) Studies on the alkalinity of some silicate minerals. U.S. Geol. Survey Prof. Paper 185-A, pp. 1-13.

Tolman, C. F. (1937) Ground Water. McGraw-Hill Book Co. Inc., New York. 593 p.

Troedsson, T. (1955) Vattnet i skogsmarken. Kgl. Skogshögskolans Skr. 20.
VANHALA, R. (1959) Saatavissa olevien pohjavesimäärien arvioiminen. Geologi 11, n:o 2, pp. 16-17.

V $\ddot{R E}, M$. (1961) On the quantity and quality of the water discharged from fairly small areas. Maa- ja Vesiteknillisiä tutkimuksia 9.3, pp. 1-32.

VIRO, P. J. (1953) Loss of nutrients and the natural nutrient balance of the soil in Finland. Comm. Inst. Forest. Fenniae 42, pp. 3-51.

Manuscript received, February 12, 1971. 